\title{
PERKEMBANGAN SENI TARI: PENDIDIKAN DAN MASYARAKAT
}

\author{
Dwi Anggraini \\ dwianggraini@unib.ac.id \\ Universitas Bengkulu \\ Hasnawati \\ Universitas Bengkulu
}

\begin{abstract}
Abstrak
Tujuan penelitian ini adalah untuk mendiskusikan tentang perkembangan seni tari baik dari sudut pandang pendidikan dan perkembangannya di masyarakat. Mengingat begitu banyak nilai-nilai luhur yang dapat diambil dari seni tradisi, khususnya seni tari, maka perlu dipertahankan eksistensi seni tari tradisi tersebut melalui berbagai cara agar dapat sampai kepada penikmat seni, termasuk siswa sebagai pewaris seni tradisi itu sendiri. Adapun isu-isu yang dibahas dalam artikel ini adalah tentang perkembangan seni dari beberapa dekade, seni tradisional Bengkulu dan perkembangan seni itu sendiri di dalam dunia pendidikan.
\end{abstract}

Kata kunci: Perkembangan, Seni Tari, Pendidikan, Masyarakat.

\section{PENDAHULUAN}

Berbicara tentang perkembangan, tentunya kita berbicara tentang tradisi. Keberadaan seni tradisi, seperti yang dianalogikan oleh I Made Bandem (2004) bahwa seni diibaratkan sebagai benda kuno, antik, dan semakin lama semakin sulit ditemukan. Kadang benda-benda itu lupa untuk dilihat, jauh dari perhatian, apalagi untuk dihargai. Benda itu tetap pada tempatnya, tak tersentuh hingga akhirnya berdebu atau mungkin berlumut, dan parahnya tergusur eksistensinya dan hancur tak berbekas. Namun jika benda seni ini bertemu dengan orang yang benar-benar cinta akan keantikan, maka benda ini akan dipungut, dibersihkan, digosok hingga mengkilap dan menjadi benda mahal. Di lain hal, pencinta benda antik ini biasanya akan mencari tahu asal muasal benda tersebut. Benda-benda antik biasanya menyimpan berbagai informasi tentang proses penciptaan maupun fungsinya. Sejarah, nama, kegunaan hingga keunikan apa yang dimilikinya hingga menjadikannya sangat menarik.Begitulah seni tradisi.
Analogi yang sederhana tersebut sebenarnya belum mampu mewakili tantangan kompleks yang harus dihadapi seni tradisi. Apalagi ketika dihadapkan oleh era globalisasi yang menghadirkan kenyataan tentang perubahan di segala sektor, cepat ataupun lambat. Sebuah era yang menuntut kesiapan manusia multidimensional: fisik, mental, intelektual, spriritual, kultural, politik, ekonomi dan sebagainya. Kondisi ini tidak datang dengan tibatiba, kita bisa menyikapi kondisi multidimensional ini dengan berbagai persiapan, melalui masyarakat dan juga dunia pendidikan.

\section{SENI TARI DALAM MASYARAKAT}

Perjalanan seni tradisi khususnya seni tari, mengalami berbagai tahapan perubahan dari masa ke masa. Setiap perubahan yang terjadi memiliki ciri tersendiri terkait langsung dengan periode yang dilaluinya. Periodesasi perkembangan seni tari di indonesia dibagi menjadi tiga tahap, yaitu dekade sekitar tahun 20.000 SM hingga 400 M ( Primitif), dekade sekitar tahun $400 \mathrm{M}$ hingga $1945 \mathrm{M}$ (Feodal), 
dan Dekade sekitar tahun 1945 sampai sekarang (Modern). Periodisasi yang pertama yatu dekade sekitar tahun 20.000 SM hingga 400 M (Primitif). Pada zaman masyarakat primitif ada 2 zaman yaitu zaman batu dan zaman logam. Pada zaman batu tari-tarian hanya diiringi dengan sorak-sorai serta tepukan tangan. Sedangkan pada zaman logam sudah terdapat pening galan instrumen musik yang ada sangkut pautnya dengan tari yaitu nekara (Nekara adalah suatu alat semacam tambur besar yang berbentuk seperti dandang terbalik atau ditelungkupkan Nekara banyak ditemukan di daerah Sumatra, Jawa, Bali, Pulau Sumbawa, Pulau Roti, Pulau Leti, pulau Slear, Kepulauan Kei,dan Papua) atau kendang yang dibuat perunggu. Diantara lukisan-lukisan yang menghias nekara itu ada lukisan yang menggambarkan penari yang pada kepalanya dihias bulu-bulu burung dan daun-daunan. Seni muncul dari ungkapan perasaan ekspresi manusia atas suatu suasana tertentu. Lonjakan kegembiraan seseorang saat memperoleh kesenangan akan membentuk gerakan ekspresif, lompatan manusia purba ketika berburu binatang juga terjadi secara spontan. Gerakan-gerakan inilah yang kemudian mengkristal dan disusun dalam bentuk tarian. Dari berbagai peristiwa sehari-hari kemudian terlahir bentuk-bentuk rangkaian gerak yang diwujudkan dalam bentuk upacara ritual masyarakat purba. Dengan diiringi pukulan-pukulan genderang dan sejenisnya, kelompok masyarakat purba bergerak-gerak mengelilingi api unggun yang menyala sambil melantunkan mantra-mantra dan nyanyiannyanyian persembahan bagi nenek moyang mereka. inilah cikal bakal tumbuhnya tari.

Tari primitif merupakan tari yang berkembang di daerah yang menganut kepercayaan animisme, dan dinamisme. Tari ini lebih menekankan tari yang memuja roh para leluhur dan estetika seni. Tari primitif biasanya merupakan wujud kehendak berupa pernyataan maksud dilaksanakan dan permohonan tarian tersebut dilaksanakan. Ciri tari pada zaman primitif adalah kesederhanaan kostum, gerak dan iringan menjadi lebih dominan bertujuan untuk kehendak tertentu sehungga ungkapan ekspresi yang dilakukan berhubungan dengan permintaan yang diinginkan. ciri-ciri tari primitif antara lain: (1) Gerak dan iringan sangat sederhana berupa hentakan kaki, tepukan tangan/simbol suara/gerak-gerak saja yang dilakukan; (2) Gerakan dilakukan untuk tujuan tertentu misalnya menirukan gerak binatang karena berburu, proses inisiasi, kelahiran, perkawinan, panen; (3) Instrumen sangat sederhana terdiri dari tifa, kendang, intrumen yang hanya dipukul secara tetap bahkan tanpa memperhatikan dinamika; (4) tata rias sederhana bahkan bisa berakulturasi dengan alam sekitar; (5) tari bersifat sakral karena untuk upacara keagamaan; (6) tarian primitif tumbuh dan berkembang pada masyarakat sejak zaman prasejarah yaitu zaman sebelum munculnya kerajaan sehingga belum mempunyai pemimpin secara formal. Kehidupan masyarakat masih bergerombol, berpindahpindah dan bercocok tanam; (7) tarian primitif dasar geraknya adalah maksud dan kehendak hati dan pernyataan kolektif; (8) atribut pakaian menggunakan bulu-buluan dan daun-daunan; (9) formasi pada tarian primitif biasanya berbentuk lingkaran karena menggambar kekuatan; (10) tarian ini berkembang pada masyarakat yang menganutpola tradisi primitif/purba di mana berhubungan dengan pemujaan nenek moyang dan penyembahan leluhur. Contoh tari primitif tari bailita dan tari dayang modan.

Periodisasi selanjutnya yaitu dekade sekitar tahun 400 M hingga 1945 M ( Feodal ). Jenis Tari zaman feodal ini ditandai dengan bermunculan para pakar tari yang memberikan macam-macam definisi. Tokoh-tokoh tersebut antara lain Curt Sach, Soedarsono, Corry Hamstrong, La Mery dan lain sebagainya. Pada zaman ini tari memiliki berbagai fungsi antara lain tari upacara, tari hiburan, tari pertunjukan. Tari yang berfungsi sebagai upacara ritual dan yang berfungsi sebagai hiburan pribadi sebagian tidak tercakup karena tari ritual pada umumnya lebih mementingkan tujuan dari pada bentuk penyajiannya, sedangkan tari hiburan lebih mementingkan keikutsertaan penari dalam tari itu 
dari pada kenikmatan untuk menontonnya. Pada zaman feodal ini tari di Indonesia banyak dipengaruhi oleh kebudayaan yang datang dari luar khususnya India. Selanjutnya muncul Islam melalui kerajaan-kerajaan di Indonesia saat itu, serta pengaruh perluasan wilayah bangsa barat yang kemudian membawa situasi tari di Indonesia lebih modern. Perkembangan tari zaman feodal dianggap baik karena pengaruh agama hindu, seni tari merupakan bagian yang penting dalam upacara keagamaan yang salah satu buktinya yaitu terdapat gambar atau relief candi yang menggambarkan para penari sedang menari diiringi beberapa instrumen musik.

Dalam agama hindu tari sering digunakan sebagai sarana pemujaan kepada dewa, terutama pada dewa Wisnu dan dewa Siwa, dan yang paling erat hubungannya dengan tari adalah dewa Siwa, terbukti dewa Siwa sering disebut dengan Siwa Nataraja (Siwa raja dari penari), Nahanata (penari besar), dan natapriva. Dalam kitab Regeveda (salah satu kitab suci Hindu) disebut dewa Indra, dewa Marut dan dewa Acvni sebagai dewa tari. Dalam kitab Veda juga di sebutkan bahwa dewa Bayu (angin), dewa Agni (api) dan dewa Surya (matahari) sebagai dewa penggerak dunia.

Menurut kepercayaan Hindu, para penari yang menari untuk kepentingan agama merupakan kekasih dewa (devadasi). Pengaruh predikat kekasih dewa sampai sekarang masih membekas di bali, tempat berkembangnya agama hindu dharma.Pada relief candi Borobudur, prambanan dan dieng terdapat relief yang menggambarkan penari wanita sedang menghibur raja dan keluarganya (bangsa istana). Thomas Stamfort Raffles dalam bukunya History of Java mengatakan, bahwa ronggeng merupakan tarian wanita yang khusus untuk hiburan kaum lakilaki. Tari rongeng tidak selalu itarikan oleh penari wanita, melainkan juga oleh penari peria berbusana wanita (iravesti). Di Surakarta pada awal abad XX ronggeng dipakai untuk menyebutkan penari wanita bayaran. Dalam serat centbini dan cabolang disebutkan bahwa ronggeng atau teledak sebagai penghibur harus dibayar dengan tarif tertentu. Ronggeng sebagai tarian hiburan sering mengikutsertakan para penontonnya untuk terlibat menari bersama, sekarang lebih dikenal dengan tari tayub. Tari ronggeng/tayub meskipun merupakan tarian hiburan tetapi juga mendapat perhatian dari lingkungan kerajaan.

Zaman feodal juga banyak dipengaruhi oleh pengaruh agama Islam. Pengaruh agama Islam yang membawa seni tari lebih berkembang karena digunakan sebagai media penyebaran agama Islam terutama di kerajaan Mataram, Kesultanan Cirebon dan Kerajaan Demak. Pada zaman ini juga muncul beberapa topeng antara lain panji kasatriyan, candra kirana, handoyo, raton, klano, denowo, tembem, pentul dan lain sebagainya. Zaman Indonesia islam ditandai oleh datangnya para pedagang dari india barat melalui Gujarat. Mereka selain berdagang juga menyebarkan agamanya, yakini agama islam. Namun demikian agama islam yang mereka bawa sudah kena pengaruh hindu, atau dengan kata lain telah berbau kehinduan. Islam masuk ke Indonesia pada abad XIII yaitu ditandai dengan munculnya kerajaan islam di Sumatra Utara, di Jawa mulai pada saat berdirinya kerajaan demak menggantikan Majapahit sekitar abad XV. Di Jawa Barat terdapat dua gaya tari yaitu gaya Sunda dan gaya Cirebon. Di Jawa Tengah perkembangan tari ditandai dengan lahirnya karya sastra-sastra yang berupa babad di dalamnya memuat tentang informasi-informasi tentang tari.

Setelah zaman invasi (perluasan wilayah) bangsa Barat, seni tari lebih berkembang hal ini terbukti dengan banyaknya tari yang diciptakan oleh penata tari dan bangsawan antara lain tari Bedhaya, Srimpi, beksan, wireng, dan drama tari (sendratari). Pada zaman feodal / penjajahan juga banyak muncul tari yang bertemakan kepahlawanan/heroik antara lain tari pejuang, bandayuda, prawiroguna, keprajuritan dan lainlain.

Peroidisasi yang ketiga yaitu dekade sekitar tahun 1945 sampai sekarang (Modern). Jenis tari zaman modern ini ditandai dengan 
munculnya koreografer-koreografer individu yang menciptakan karya-karya baru, lebih sebagai ekspresi diri dari pada ekspresi komunal. Gagasan koreografer individual sebagai sebuah aspek penting dari dampak kebudayaan barat. Tokoh-tokoh tari modern antara lain Isadora Duncan, Martha Graham, Doris Humphrey, Mary Wigman dan lain sebagainya. Tokoh tari modern dari Indonesia salah satunya adalah Sardono W. Kusumo dan Sal Murgiyanto. Karya tari yang muncul pada zaman modern ini antara lain Dongeng dari Dirah, Meta Ekologi, Hutan yang Merintih. Di Indonesia pada masa setelah merdeka juga muncul tari yang bernuansa tradisional garapan baru yaitu tari Karno Tanding, Tari Retno Ngayuda, Tari Retno Tinanding, Tari Menak Koncar, dan sebagainya

\section{Perkembangan Tari Tradisional Bengkulu}

Berbicara tentang perkembangan, ada tiga hal yang menjadi sorotan, yaitu perkembangannya dilihat dari segi bentuk pertunjukkan berkaitan dengan perubahan fungsi, perkembangan dari segi pewarisan, dan perkembangan dari segi penggarapan.

\section{Perkembangan bentuk pertunjukkan berkaitan dengan perubahan fungsi}

Seperti yang kita ketahui, bahwa perkembangan seni pertunjukkan khususnya tari di kota Bengkulu yang paling menjadi sorotan adalah kesenian Tabot, yang di dalamnya juga terdapat tarian yang ide garapannya berangkat dari ritual pembuatan tabot, atau pecahan dari kegiatan-kegiatan yang ada dalam ritual Tabot. Tari tabot ini dahulunya masuk kepada kategorisasi tari ritual, yakni penari berhubungan langsung dengan Sang Pencipta untuk tujuantujuan tertentu. Pada proses penggarapannya, tari ritual ini melibatkan unsur magis yang sangat kuat. Menurut kepercayaan bahwa dengan memanggil roh-roh nenek moyang maka pertunjukkan atau ritual yang dilakukan akan berjalan lancar. Sebaliknya jika tidak maka akan menjadi malapetaka.
Seiring dengan waktu dan masuknya ajaran Islam, maka unsur magis itu sedikit demi sedikit dihilangkan. Seni tari yang awalnya berfungsi sebagai seni ritual berubah menjadi seni tontonan. Tari sebagai tontonan disajikan khusus untuk dinikmati untuk kemasan pariwisata, utuk penyambutan tamu-tamu penting, dan untuk festival seni. Penggarapannya sudah dikemas dan dipersiapkan menjadi sebuah tarian bentuk yang tekah melewati proses penataan, baik gerak tarinya maupun musik iringannya sesuai dengan kaidah-kaidah artistiknya.

Selain tari Tabot, dalam kesenian Bedendang juga terdapat tarian-tarian yang menjadi ide dalam membuat tari kreasi baru. Misalnya saja tari Sapu Tangan, Piring, Selendang Panjang dan sebagainya. Berdasarkan penelitian Anggraini (2012) bahwa untuk data mempelajari kesenian tradisi Bedendang (termasuk tari) harus melalui proses Belimau. Ritual ini dimaksudkan untuk menghindari bala yang dapat menimpa penari yang akan belajar tari tersebut. Namun semakin banyaknya seniman Bengkulu yang kreatif, maka tarian yang dulunya membutuhkan ritual untuk dapat menarikannya memiliki kemungkinan yang besar untuk ditarikan secara bebas tanpa meninggalkan nilainilai tradisinya.

\section{Perkembangan dari Segi Pewarisan}

Pewarisan merupakan upaya untuk mempertahankan eksistensi seni tradisi di masyarakat. Seni tradisi yang merupakan jati diri masyarakat dalam suatu komunitas (daerah). Untuk dapat mempertahankan jati diri tersebut, tentu seni tradisi itu harus diwariskan kepada anak cucu, generasi muda secara turun temurun. Dalam kehidupan bermasyarakat, Bengkulu sudah mencoba untuk mempertahankan jati diri tersebut melalui sanggar-sanggar seni. Misalnya sanggar Mayang Sari yang sekarang berubah nama menjadi Arastra, Puspa Kencana, Gentar Alam, Essy Studio, Artistika dan lain sebagainya. Sanggar-sanggar ini eksis membawa seni tradisi Bengkulu ke berbagai pertunjukan, tidak hanya di 
dalam kota saja, tetapi juga keluar kota atau bahkan ke luar negeri. Ini menandakan bahwa usaha untuk mewariskan kebudayaan nenek moyang kepada anak cucu masih bias dipertahankan. Dapat dilihat bahwa anggota dari sanggar tersebut tidak hanya remaja-remaja saja, tetapi juga dimulai dari anak-anak kecil usia SD atau un lebih kecil lagi.

Selain sanggar-sanggar, komunitas seniman tradisi juga memprogramntuk melatihkan seni tradisi yang mereka miliki kepada generasi muda. Seperti misalnya komunitas kesenian Bedendang Kelurahan Berkas masih tetap hidup dan eksis dalam masyarakat. Setiap malam minggu atau sering juga berganti hari, diadakan latihan rutin di mana tidak hanya orang-orang tua saja yang belajar gendang, silat ataupun tari. Anak-anak kecil juga antusias dengan kegiatan ini dan ikut andil dalam latihan. Tidak hanya yang ikut menari saja yang hadir, tetapi masyarakat sekitar berbondongbondong melihat dan menyaksikan proses latihan tersebut sebagai tanda mereka juga peduli dan ingin terus menjadi penikmat seni tradisi.

Pewarisan tidak hanya terjadi di dalam kehidupan masyarakat saja (informal), tetapi pewarisan juga bias dilakukan melalui pendidikan formal. Sebagai contoh, di PGSD FKIP Universitas Bengkulu pada mata kuliah Pendidikan Seni Tari dan Drama, mahasiswa dituntut untuk menggarap tari baru (kreasi), dan yang diutamakan adalah yang sumber idenya berangkat dari seni tradisi daerah setempat dan juga tari pendidikan. Pada tahun 2010, hasil karya mahasiswa ditampilkan di Taman Budaya Kota Bengkulu. Mereka menggarap dramatari yang berjudul Serindang Bulan dengan dua Versi yang berbeda. Satu kelompok mengutamakan alur cerita dengan penokohan yang kuat, sedangkan kelompok lainnya memberikan sentuhan berbeda yaitu memberikan sentuhan humoris. Kedua pertunjukkan ini sangat menarik dan mereka tidak meninggalkan unsur-unsur penting yang tidak boleh ditinggalkan. Masih banyak lagi karya mahasiswa yang beranjak dari tradisi, dimulai dari segi perkebunannya, nelayan, suku Enggano dan lain-lain. Kegiatan ini berlangsung setiap tahunnya dan tidak hanya seni tari saja, tetapi juga seni musik yang mengutamakan penggarapan lagu daerah sebagai basis penciptaannya.

\section{Perkembangan dari Segi Penggarapan}

Ide muncul karena ada stimulus atau rangsangan. Adapun jenis stimulus yaitu visual (muncul dari sesuatu yang terihat), audio (muncul dari sesuatu yang didengar), peraba (muncul dari sesuatu yang dirasakan oleh kulit), kinestetik (muncul dari gerak-gerak indah yang sudah ada sebelumnya), dan ideasional (timbul dari aktivitas manusia, cerita, dongeng, puisi dan lainlain). Stimulus dalam membuat tarian tidak hanya berasal dari tarian yang sudah ada dan juga dari cerita rakyat, tetapi juga bisa menggarap tari yang distimulus melalui metode mimesis (peniruan), baik itu peniruan terhadap tingkah laku manusia maupun alam sehingga tari yang dikembangkan akan lebih beragam. Pengembangan tari dari segi bentuk penggarapan ini (komposisi/koreaografi) dilakukan dengan berbagai pertimbangan artistik tanpa meninggalkan nilai-nilai tradisi yang sudah ada. Artinya jika setiap ide penggarapan tari kreasi baru yang didasari pada tradisi, maka pakem atau aturan dan gerak dasar dari tari sebelumnya harus tetap terlihat.

Seperti misalnya dalam mengembangkan gerak tari Tabot, tentu ada gerak dasar tari Tabot yang harus tetap digunakan dan dapat dikembangkan. Sehingga setiap tarian Tabot yang diciptakan menjadi beragam namun memiliki benang merah karena berasal dari sumber yang sama. Tidak hanya tari Tabot, seperti yang telah dipaparkan sebelumnya bahwa dalam seni Bedendang juga terdapat tari-tarian yang dapat dikembangkan menjadi karya tari kreasi baru yang menarik tanpa meninggalkan kaidah gerak yang terdapat di dalam gerak tari tersebut. Langkah tiga seluk yang menjadi ciri gerak dalam tari saputangan dapat diambil sebagai gerak dasar yang menciri namun dapat dikembangkan menjadi langkah tiga seluk yang 
baru untuk tari yang baru pula. Tentunya dari sini akan muncul tari saputangan yang baru dan bervariasi, tanpa meninggalkan pakem yang sudah ada.

\section{PERKEMBANGAN SENI TARI DALAM DUNIA PENDIDIKAN}

Seperti yang sudah dipaparkan sebelumnya bahwa pewarisan seni tradisi tidak hanya dapat dilakukan melalui kegiatan yang dibangun di sanggar-sanggar seni (informal) saja. Pewarisan juga sangat mungkin untuk dilakukan melalui dunia pendidikan formal. Melalui pembelajaran Seni Budaya dan Prakarya (SBdP) seni tari khususnya dapat ditularkan kepada generasi muda. Tentunya dalam hal ini guru harus mampu menguasai bidang seni tari itu sendiri, setidaknya dalam hal mencipta dan mengkomposisi tari sesuai dengan tingkat perkembangan peserta didik.

Dalam dunia pendidikan formal, pendidikan seni tari tidak menuntut siswa untuk menjadi seorang penari yang profesional. Artinya produk tari yang dihasilkan bukanlah untuk kebutuhan pentas, melainkan adalah proses kreatif siswa. Seperti yang diungkapkan oleh Sal Murgianto dalam Masunah (2003) bahwa nilai tari dalam dunia pendidikan tidak terletak pada latihan kemahiran atau keterampilan gerak saja, tetapi lebih kepada kemungkinan untuk membuat siswa mampu mengembangkan daya ekspresinya. Pendidikan melalui tari atau dewasa ini lebih dikenal dengan tari pendidikan merupakan . Jika siswa sudah sampai ke taraf mengapreasiasi maka seni tradisi tidak akan menjadi barang antik yang berdebu dan terlupakan.

Pembelajaran tari dapat dilakukan dengan menggunakan metode kreatif. Dalam metode ini, tari yang diciptakan berasal dari siswa, oleh siswa dan untuk siswa. Maksudnya adalah tema dalam membuat tari boleh ditentukan oleh guru, namun pemilihan gerak, pengolahan gerak dan bagaimana siswa mengkomposisikannya diserahkan sepenuhnya kepada siswa. Hal ini dimaksudkan agar siswa mampu untuk mengambil keputusan sendiri untuk kepentingan kelompok.

Dalam pembelajaran tari, yang menjadi penilaian adalah bukan bagus atau tidaknya tari yang dihasilkan, melainkan adalah proses kreatif yang mereka lalui hingga sikap positif yang terbentuk melalui pembelajaran tari. Misalnya percaya diri, mampu bekerjasama, berani mengambil keputusan, mampu bersosialisasi, mampu mengungkapkan pendapat dan lain sebagainya.

Ide dalam membuat tari dalam pendidikan formal bisa saja berasal dari lingkungan dan aktivitas manusia. Guru juga bisa mengarahkan proses kreatif ini pada seni tradisi yang ada di daerah masing-masing. Dalam hal ini, guru tidak mengajarkan tarian bentuk, tetapi guru menstimulus siswa untuk membuat tarian baru dari tari tradisi yang sudah ada. Tentunya disesuaikan dengan kurikulum yang berlaku. Pembelajaran menjadi media bagi guru untuk menanamkan rasa seni, sikap kreatif serta menumbuhkan motivasi untuk menghargai seni kepada siswa. Dari sinilah akan muncul rasa memiliki terhadap seni tradisi, sehingga ketika tari tradisi kita di klaim orang luar seperti Reog Ponorogo, maka akan ada pembelaan dan usaha untuk mempertahankan seni tradisi tersebut. Dengan demikian perkembangan atau pewarisan seni tradisi, khususnya di kota Bengkulu tidak terputus hanya pada sanggar-sanggar semata, yang notabene anggotanya merupakan orangorang tertentu saja, yang berminat maka masuk sanggar, yang tidak maka acuh tak acuh.

\section{SIMPULAN}

Seperti pepatah mengatakan "banyak jalan menuju Roma", tentunya banyak pula cara yang bias ditempuh untuk mempertahankan seni tari tradisi yang ada di kota Bengkulu. Pilihannya bisa saja melalui pendidikan formal maupun informal. Melalui pendidikan manapun akan mampu menjadi cara untuk mewariskan seni tradisi kepada generasi muda agar barang antik (seni tradisi) tersebut tidak lagi menjadi 
seonggok barang rongsokan yang tidak bermakna, berdebu, dan tidak mendapat perhatian. Namun benda antik tersebut mampu berada pada bargaining position yang tinggi.

\section{DAFTAR PUSTAKA}

Anggraini, Dwi. 2012. Pengembangan Multimedia Interaktif dengan Menggunakan Model ADDIE untuk Pembelajaran Seni Tari pada Siswa Sekolah Dasar (Tesis). Bandung: Sekolah Pascasarjana UPI.

Bandem, I Made. 2004. Seni Tradisi Menantang Perubahan: Seni Tradisi di Tengah Arus Perubahan. Padang Panjang: Padang Panjang Press.

Masunah, Juju. 2003. Seni dan Pendidikan Seni: Tari Pendidikan Metodologi Pengajaran Tari di Sekolah. Bandung: P4ST UPI Bandung.

Narawati, Tati. 2003. Seni dan Pendidikan Seni: Dampak Perkembangan Ekonomi Terhadap Seni Pertunjukkan di Indonesia. Bandung: P4ST UPI Bandung.

Sekarningsih, Frahma dan Heny Rohayani. 2006. Kajian Lanjutan Pembelajaran Tari dan Drama I. Bandung: UPI Press.

\section{Sumber Lain:}

http://sabihahmutia.blogspot.com http://macam-macam-tarian-daerah.blogspot.com http://kebudayaankesenianindonesia.blogspot.co

$\mathrm{m}$ 